\title{
離乳期乳児における筋活動咀嚼リズムの観察
}

\author{
芥子川浩子, 仲岡佳彦, 山田 賢, 近藤覀子, 長谷川信乃, 田村康夫 \\ 朝日大学歯学部小览歯科学講座（主任：田村 康夫 教授） \\ 〔受付：平成11年 4 月12日〕
}

\section{Electromyographic evaluation of chewing rhythm in infants at the weaning period}

\author{
Hiroko Keshikawa, Yoshihiko Nakaoka, Satoshi Yamada, Tsuguko Kondo, \\ Shinobu Hasegawa, Yasuo Tamura \\ Department of Pediatric Dentistry, Asahi University School of Dentistry \\ (Director: Prof. Yasuo Tamura) \\ [Received: April 12, 1999]
}

Key words: chewing rhythm, mastication pattern, EMG, weaning period, infants

\begin{abstract}
The purpose of the study was to investigate the characteristics of mastication in infants by evaluating the electromyographic chewing rhythm of the masticatory muscles and VTR, and to discuss the development of masticatory function in infants at the stage of the weaning period. Sixty subjects were divided into the following five groups, G0 (the sucking group as a control), G1 (up to 8 wks after the initiation of weaning), G2 (up to 16 wks), G3 (up to $24 \mathrm{wks}$ ) and $\mathrm{G} 4$ ( more than $25 \mathrm{wks}$ ).

When compared to the control both the chewing cycle time and the burst duration in the temporal muscle became significantly longer in $\mathrm{G} 1$ and $\mathrm{G} 2$, and then declined gradually in $\mathrm{G} 3$ and $\mathrm{G} 4$. The mastication pattern of infants can be classified into three types, such as continuous tongue compression, cyclic tongue compression and the maturation type. The frequency of the maturation type was significantly increased from G1 (2.6\%) to G4 (49.5\%) as the time proceeded from the initiation of weaning.

The coincidence of the bursts of the temporal muscle and the suprahyoid muscles was recognized during each chewing cycle in the earlier period of weaning, while the burst timing of the both muscles were, thereafter, differentiated gradually. Therefore, the development of masticatory function in the weaning period infants disclosed that the function of the jaw closing muscle and of the jaw opening muscles is differentiated gradually.
\end{abstract}

抄録 乳児離乳期における咀嚼運動の発達と各時期での特徴を明らかにする目的で, 離乳食咀嚼運動時に おける咀嚼運動りズムと，側頭筋と舌骨上筋群の筋協調パターンを筋電図を用い検討した．被検児は吸啜 群を対照とし離乳食を開始してから 8 週間隔で 1 群から 4 群に分けた．筋活動協調パターン評価では持続 的舌圧接型, 周期的舌圧接型および成熟型の 3 タイプに分類し，今回は特に成熟型の咀緭運動中に占める 割合について検討した.

その結果，離乳開始から16週頃までは咀嚼サイクル時間，持続時間ともに長い咀嚼パターンを示し，ま た閉口筋である側頭筋と開口筋である舌骨上筋群とが同時に活動する協調運動を示していたが，離乳の進

連絡先：テ501-0296 本巣郡穂積町穂積 1851 
行に伴い閉口筋と開口筋とが交互に活動する成熟型の割合が高くなっていた．それ故，この時期の咀嚼機 能は閉口筋と開口筋の機能的な分離が進み，次第に発達することが示唆された.

\section{I. 緒言}

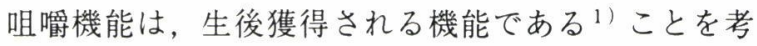
慮すると, 乳児期は咀嚼機能の発達段階でみると吸啜か ら咀嚼への移行期であり,この時期に健全な咀嚼の発達 を促すことは極めて重要である.

我々は, 咀嚼機能の発達の観点から乳児の吸啜運動を 検討し, 吸啜時には口腔周囲筋筋活動に咀嚼時とは異な る筋の協調パターンがみられること，また月歯により舌 骨上筋群の活動が増大することを報告した $\left.{ }^{2}, 3\right)$ 。 そし て,さらに離乳食開始後間もない乳児の咀嚼運動を, ビ デオ解析と口腔周囲筋筋電図を用い定性的に分析した結 果, この時期の一連の摂食行動は(1)乳児が食物を目で認 識しての開口運動, (2)摂取運動, (3)咀嚼様運動, (4)嚥下 運動の順に分類でき，基本的には咀嚼運動が既に確立さ れていることが分かってきた。またこの時期では舌骨上 筋群を活発に使用し，肉眼的にみて閉口筋の咀嚼リズム が不明瞭であるという特徴的な咀嚼パターンを示すこと も報告してきた ${ }^{4}$ ．しかし定量的な分析にまでは至って いなかった。

そこで本研究は, 乳児離乳期における咀嚼の発達と各 時期の特徴を明らかにする目的で, 上記の(3)咀嚼様運動 時における咀嚼リズムと筋協調パターンの变化を離乳開 始からの週齢によって検討したものである。

\section{I．被検児および方法}

\section{1. 被検児および被検食品}

被検児は, 吸啜運動時の口腔周囲筋笳活動を検討し, その後離乳食に移行した乳児20名（男児11名，女児 9 名） を対象とした。問診により彼らの離乳食開始期（平均 22.4週齢）を調べ，開始期からの週経過で 8 週以下（1 群：11名，平均29.0週齢)，16週以下（2 群：15名, 平 均35.0週歯)，24週以下（3群：8名, 平均41.6週歯令）お よび25週以上（4群：6名，平均59.2週齢）の 4 群に分 け検討した。また同被検児の吸啜期（平均週齢：13.6土 6.8週時）における吸啜運動時筋活動をコントロールと した。

被検食品として，その時期に普段家庭で乳児に与えて いる離乳食を母親に持参してもらい観察に供した。尚， 咀嚼運動は, 離乳食の内容や硬さ・調理形態や，また乳
児の全身的発達段階により異なるため, 離乳食の中から 全被検者に共通していた米飯を選択した。米飯の調理形 態は，事前に離乳食の進め方の目安とした厚生省「離乳 の基本」 ${ }^{51}$ に照らし合わせ,つぶしがゆ, 全がゆ, 軟 飯, ご飯（普通のかたさ）に調理されたものを被検食品 とした。

\section{2. 筋電図記録}

筋電図記録は，シールドルーム内に普段家庭で離乳食 を与えている姿勢で母親と乳児を座らせ，離乳食咀嚼時 の筋電図を記録した。記録は，本教室の方法に従い2-4 片側の側頭筋前部，咬筋浅部，口輪筋および舌骨上筋群 の 4 筋より双極表面銀電極を用い筋活動電位を導出し, データレコーダに保存した。また被検児正面に設置した ビデオカメラを用い顎顔面の動きをモニタし，ビデオフ オーマッ夕（日本光電社製，VY302B）およびフレーム シンクロナイザ（日本光電社製，FS400）を用い，顎顔 面の動きと口腔周囲筋筋活動波形を, 同時に同一画面で ビデオレコーダ (VTR) にも記録した（図 1)。この記 録は咀嚼運動時の顎顔面の動きと各筋活動との協調を検

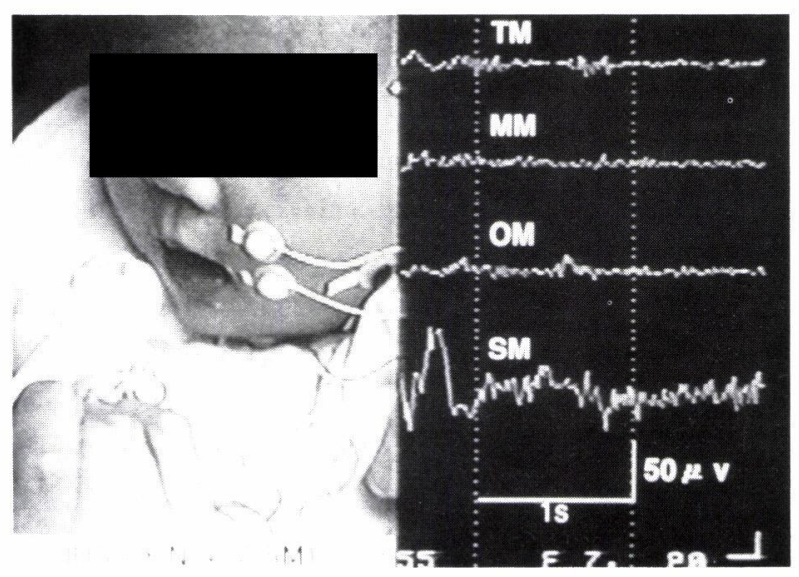

図 1 モニ夕上に 2 分割画面で表示された咀嚼 運動中の被検児例，顎顔面の動きと筋電 図波形右端とは同期している。

Fig. 1 The maxillofacial view (left) and electromyograms (right) during chewing foods were scanned simultaneously in two sections on the monitor. Maxillofacial motions coincide with the right side end of the EMG activities. The temporal, masseter, orbicularis oris and suprahyoid muscles are represented as TM, $\mathrm{MM}, \mathrm{OM}$ and SM, respectively 


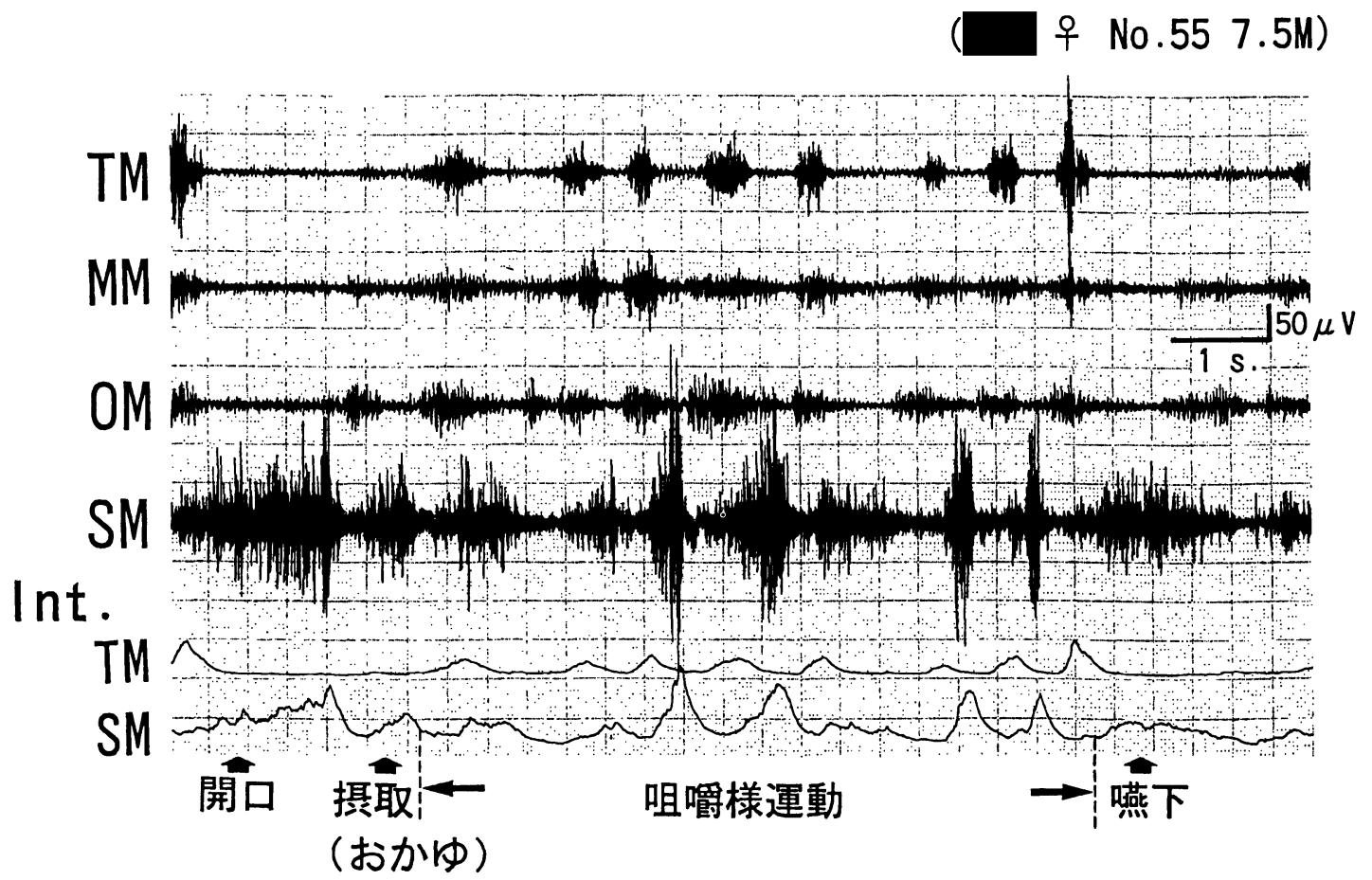

図 2 離乳食咀嚼時の口腔周囲筋筋活動例

Fig. 2 Raw and integrated EMG sample traces of an infant during chewing foods. The temporal, masseter, orbicularis oris and suprahyoid muscles are represented as TM, MM, OM and SM, respectively

討する上での参考とした.

\section{3. 計測方法}

計測には，データレコーダから $25 \mathrm{~mm} / \mathrm{s}$ でサーマルア レイレコーダに再生した咀嚼運動時の筋電図を用い, 開 ロから嚥下まで連続して最も活動が明瞭に出現している 一連の波形を，VTRで確認した上で選択し計測に供した (図 2 ). 以前我々は, 離乳食の咀嚼運動時における口腔 周囲筋筋活動を定性的に分析した結果, この時期の一連 の咀嚼行動は, 乳児が食物を目で認識しての(1)開口運動, (2)食物の揁取運動, (3)咀緭様運動, (4)嚥下運動の順で時 間経過により分類することができることが明らかになっ ている ${ }^{4)}$ ，そこで，本観察での対象波形として，咀嚼開 始から嚥下直前までの(3)咀嚼様運動について観察した。

咀嚼リズム計測点および計測方法は，側頭筋（側頭筋 が不明瞭な場合，咬筋）を対象に，各波形の活動開始 期 - 活動終了期を肉眼的に判定し, 活動開始から次の活 動開始までを咀嚼サイクル時間とし，また各活動におけ る活動開始期から終了期までの時間を持続時間として, ノギスを用いて計測した．乳児の咀夁様運動は比較的短 く嚥下までに要する咀嚼回数はほとんどが10回以内であ るが，それを越える場合は，咀翾開始から10波形を計測
対象とした。

また咀嚼機能の発達を評価するため，側頭筋（咬筋） と舌骨上筋群の筋活動協調パターンにおいて，各筋活動 を積分波形に変換し観察することにより，図 3 の持続的 舌圧接型, 周期的舌圧接型および成熟型の 3 タイプに定 性的に分類した．各型の定義は以下の通りである。

持続的舌圧接型 : 側頭筋の筋活動と舌骨上筋群の筋活動 において，側頭筋の 1 波形に対応する舌骨上筋群に協調 活動が認められず, 独自の連続的な活動を示すパター ン.

周期的舌圧接型：側頭筋と舌骨上筋群が一定のリズムで 協調しているものの，舌骨上筋群の活動が全体的に高く， 側頭筋の活動と明らかな重なりが認められるパターン. 成熟型：側頭筋と舌骨上筋群の活動が時間的に完全に分 かれているパターンで, 側頭筋の活動の 1 波形の終了と 舌骨上筋群の活動開始が明瞭になっているパターンとし た.

差の検定には $\mathrm{t}$-検定およびカイ 2 乗検定を用いた。 
I. 持続的舌圧接型

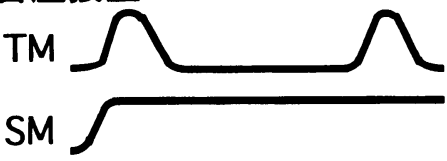

II. 周期的舌圧接型

(A)

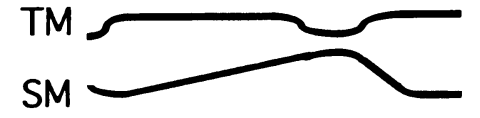

(B)

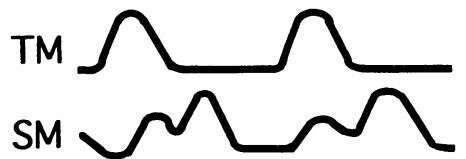

(C)

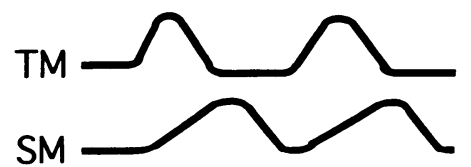

III . 成熟型

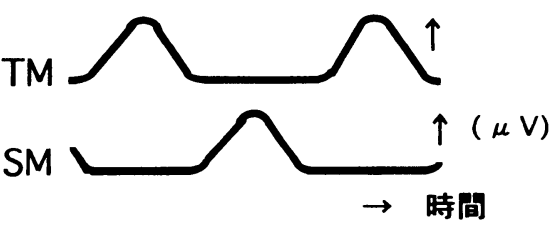

図 3 咀嚼パターンの分類

Fig. 3 Classification of the mastication pattern evaluated by the integrated EMG of the temporal and suprahyoid muscles. The mastication pattern of infants can be classified into three types, such as the continuous tongue compression type (I), the cyclic tongue compression type (II) and the maturation type (III)

\section{III. 観察結果}

1. 咀嚼サイクル時間は, 図 4 に示すように吸啜時の平 均值（SD）が690.4（177.5） msであったのに対し，1 群が748.0 (141.9) ms, 2 群が831.1 (156.8) ms, 3 群が786.5（151.3） ms, 4 群が742.0（62.9） msと, 離 乳食開始後 9 週から16週で有意に長くなり, 後は再び 短縮していた.

2. 持続時間は, 図 5 に示すように吸啜時平均值（SD） の319.6（71.2） msに比べ, 各群とも有意に長い持続 時間を示していた。1 群が429.7（103.8） ms，2 群が 464.1 (104.2) ms, 3 群が432.5（99.9） ms, 4 群が 394.7 (57.0) ms と, 離乳食開始後 9 週から16週で最 も長い持続時間を示し，後は短縮傾向を示していた。

3 . 成熟型の占める割合は, 1 群の出現頻度平均 $(\mathrm{SD})$

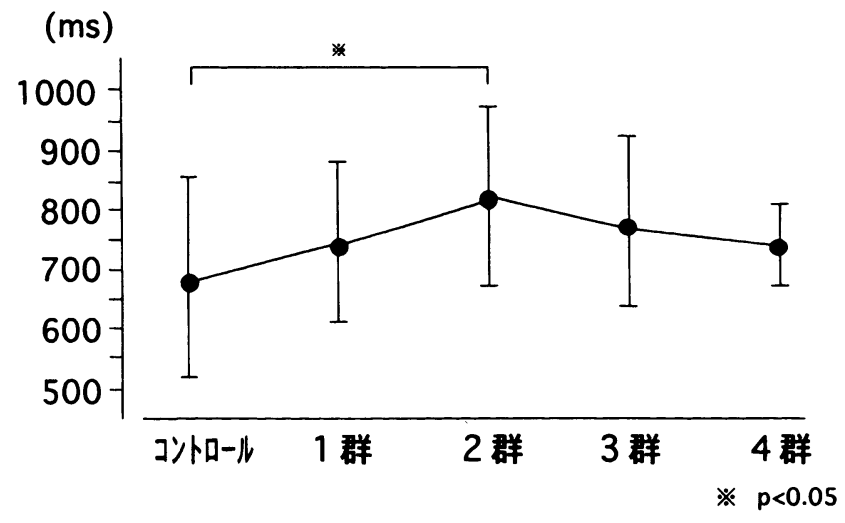

図 4 咀嚼サイクル時間の変化

Fig. 4 Changes of the chewing cycle time (mean and SD)

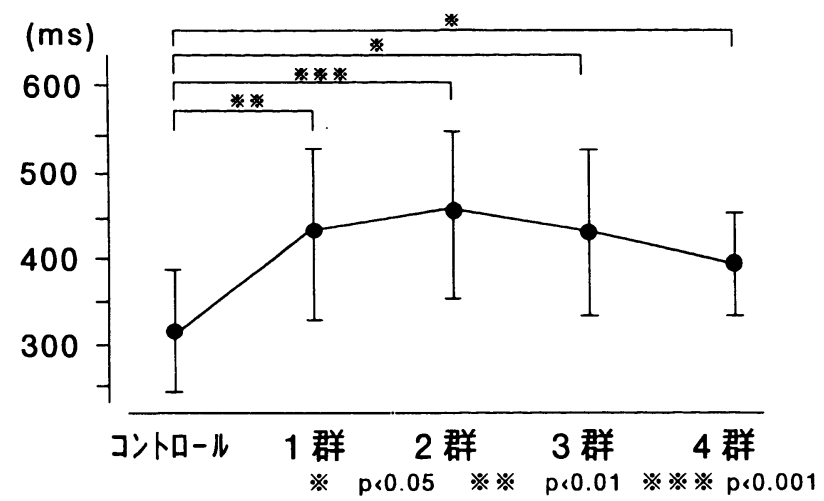

図 5 咀嚼サイクルにおける側頭筋筋活動の 持続時間変化

Fig. 5 Changes of the burst duration (mean and SD)

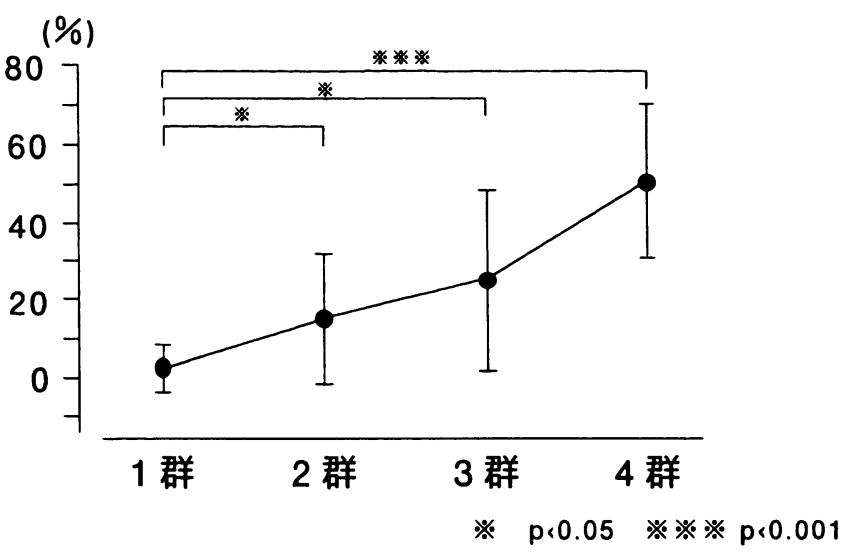

図 6 成熟型咀嚼パターンの出現頻度の変化

Fig. 6 Changes for the frequency of the maturation type 
の2.6（5.1）\%に比べ， 2 群は15.7（17.0）\%，3群は 24.9 (23.3) \%，4 群は49.5（22.6）\%と, 離乳開始か らの期間で有意 $(p<0.05 \sim p<0.01)$ に増加していた (図 6 ).

\section{IV. 考 察}

離乳食の開始時期は，舌押し出し反射が消失してくる 生後 5,6 か月が一応の目安となる ${ }^{61}$. 二木 ${ }^{7}, 81$ は小 児科医の立場から, 乳児の咀嚼機能の発達段階を視覚的 に，哺乳期，口唇食べ期，舌食べ期，歯ぐき食べ期およ び歯食べ期の 5 段階に分けている。しかし歴齢（月齢） は，満期産健常児であっても成長発育に個人差がみられ， また同月齢でも離乳の進め方が異なっている場合, 特に 離乳初期では咀嚼の発達は影響を受けることが考えられ る ${ }^{91}$. そのため本研究では，問診を行い離乳食を開始し てからの経過期間により乳児の群分けを行った．被検食 品として米飯を用いたが，米飯は母親に持参してもらう にも比較的利用しやすいという本観察実行上の利点もあ った。一方，筋電図を用いて咀嚼運動を検討する場合， 再現性を高めるために被検食品のテクスチャーを統一す る必要があるが, その点, 今井 ${ }^{10)}$ は咀嚼を嚥下まで観 察する場合, 米飯は他の食品に比較して安定した咀嚼運 動が観察されることを成人で報告している。しかし今回 の被検児は, 生後間もない乳児が主であるため, 厚生省 の改訂「離乳の基本」51に従い, つぶし粥, 全谟, 軟 飯, ご飯の状態に調理された米飯を乳児の発達段階ある いは離乳の進行にあわせて選択した。

咀嚼運動をVTRで観察すると，1，2 群乳巟は，いわ ゆる “もぐもぐ”様の咀嚼運動を行い, 咀嚼を開始して も数回の運動で讌下まで至っており, 明瞭な咀嚼りズム はみられなかった。またりズミカルな運動が出現しても 連続して長くは続かず，しかもこのとき顎の上下運動は 小さく, 前後運動が主体となっていた. 塩沢ら ${ }^{11)}$ は成 人で米飯の物理的性状を変えて咀嚼から嚥下までの検討 を行ったところ, 試料の量が増大すると咀嚼回数, 時間, 嚥下誘発回数のいずれもが増大し，また大きな食片は， 口腔内で保持される傾向にあり，米飯でも凝集性が悪い もの，例えば水分の多く含まれている場合などでは早期 に嚥下が誘発され, 咀嚼回数や咀嚼時間が減少する傾向 にあると報告している，同様のことは離乳食にもいえ， お䋆は乳汁から固形食の嚥下へと移行する時期の食品で あり ${ }^{81}$ ，また水分量も多いため嚥下までの時間が短くな ったものと思われる。ささらに, 離乳開始期の咀嚼運動は, 吸哆運動とも関係しているようにも思えた。つまり吸啜
運動時の舌の動きと咀嚼筋の協調を観察すると, 吸啜時 乳児は乳首を舌, 口唇, 㚘頁で捕捉した後, 舌で乳首を口 蓋へ押しつけ，舌中央部に生じた隆起が乳首を基底部か ら先端へとしごくように後方へ移動する舌運動パターン を示していることが明らかにされている12-14).そして この時期舌骨上筋群の活動が非常に大きく, 閉口筋であ る側頭筋や咬筋の活動は小さいことも知られている2，3， 13-17)。 それ故, 離乳期前半ではいきなり成人に近い咀 嚼運動を行うのではなく, 恐らく吸啜運動時の舌および 顎運動に近い形で咀嚼運動を開始しているものと推察さ れた，それが “もぐもぐ”様の成人とは異なる不明暸な 咀睑運動になって現れたものと考えられた。

そこで咀嚼リズムで検討すると，咀嚼サイクルと持続 時間は共に 1，2 群で長く，3，4 群では短縮する傾向 が認められた。咀嚼リズムに影響を及ほす因子としては， 当然食物の性状が関係してくる. 特に硬さの影響は大き く, 田村ら ${ }^{18)}$, 柴崎ら ${ }^{19 〉}$ の小児で食品の物性と拱食機 能について筋電図学的に検討した結果によると, 硬さが 增すにつれて咀嚼筋活動量は大きくなり, 咀嚼回数, 持 続時間も大きくなることを報告している．

本研究において，1 群から 3 群にかけては，つぶし粥 一軟飯に調理されたものが中心であり, 硬いものを食べ ていないにもかかわらず咀嚼サイクルと持続時間が長く なっていた。 また普段においてもこの時期の乳児はほと んど硬い食品を摂取していないことから, 食品の硬さ以 外の要因で, 咀嚼サイクルと持続時間が長くなったこと が考えられた。それには，第一に咀嚼運動の未熟さ，も しくは咀嚼中枢と咀嚼器官の未発達によることが考えら れた。離乳時期は機能発達の面でみると吸哆から咀嚼へ の移行期であり, 直ぐに本格的な咀嚼へ移行するわけで はない。

そこで本研究ではさらに，側頭筋と舌骨上筋群の協調 に着目し，筋協調パ夕ーンを持続的舌圧接型, 周期的舌 圧接型，成熟型の 3 型に分類し検討を行った，その結果， 離乳食を開始した時期では，舌を頻繁に使用する持続的 舌圧接型の筋協調パターンが主であり，また第一乳臼歯 が萌出を開始し始める1歳（4 群）以降では成熟型の咀 嚼パターンが著明に増加してくることが分かった，乳児 は離乳開始まで乳汁の吸引と嚥下を繰り返し行ってお り，離乳期に入ったからといって，いきなり固形食を噛 み咀嚼するのではなく, 離乳開始直後は吸啜に似通った 舌あるいは口の動きで舌骨上筋群を活発に使用し, 舌で 押しつぶす様な口の動きを行っているものと考えられ る。その咀嚼パターンがしばらく続き, 歯ぐきでの咀夁 が行える時期になると成熟型の咀嚼パターンが次第に出 
現し始め, 第一乳臼歯が萌出する 4 群では成熟型がさら

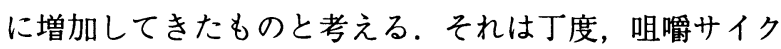
ル時間や持続時間が短縮し, リズムが比較的安定して出 現する時期とも一致していた。

\section{V. 結 論}

1. サイクル時間は, 吸啜時の平均値（SD）が690.4 (177.5) msであったのに対し， 1 群が748.0（141.9） ms, 2 群が831.1 (156.8) ms, 3 群が786.5（151.3） $\mathrm{ms}, 4$ 群が742.0 (62.9) $\mathrm{ms}$ と, 離乳食開始後 9 週か ら16週で有意に長くなり，後は再び短縮していた。

2. 持続時間は, 吸啜時平均值（SD）の319.6（71.2） $\mathrm{ms}$ に比べ, 各群とも有意に長い持続時間を示してい た. 1 群が429.7 (103.8) ms, 2 群が464.1 (104.2) ms, 3 群が $432.5(99.9) \mathrm{ms,} 4$ 群が394.7 (57.0) ms と, 離乳食開始後 9 週から16週で最も長い持続時間を 示し，後は短縮傾向を示していた。

3. 離乳開始から16週頃までは閉口筋と開口筋が同時に 活動する舌圧接型の協調運動を示していた。 それに対 し, 成熟型の占める割合は, 1 群の出現頻度平均 2.6 （5.1）\%に比べ， 2 群は15.7（17.0）\%，3 群は24.9 （23.3）\%，4 群は49.5（22.6）\%と離乳開始からの期 間で有意に増加していた。

以上より, 離乳食開始間もない頃は閉口筋である側頭 筋と開口筋である舌骨上筋群は同時に活動する特徴を有 するが, その後は両筋の機能的な分離が進み, 次第に咀 嚼が発達していくことが示唆された.

本論文要旨は第12回日本顎口腔機能学会大会（平成 9 年 3 月 28,29 日，新潟大学）において発表したものであ る.

\section{文献}

1 ) 江藤一洋: 第 2 章 咀嚼器官の発生と成長, 東京医 科歯科大学歯学部顎口腔総合研究施設編, 咀しゃく の話, 97-129, 日本歯科評論社, 東京, 1983.

2 ) Tamura, Y., Matsushita, S., Aoki, H. et al.: Development of perioral muscle activity during breast feeding in infants: Follow-up study, Ped Dent J, $6: 101-106$, 1996.

3 ) Tamura, Y., Matsushita, S., Shinoda, K. et al. : Development of perioral muscle activity during sucking in infants: a cross-sectional and follow-up study, Dev
Med Child Neurol, 40 : 344-348, 1998.

4 ) 田村康夫, 下郷 恵, 青木浩子ほか：ヒト乳児にお ける吸啜から咀嚼運動への口腔周囲筋活動の変化, 小児歯誌, $33: 271,1995$.

5 ) 厚生省児童家庭局母子保健課長: 改訂「離乳の基本」 について，小児保健研究，55：127-129，1996.

6 ）巷野悟郎：離乳食を食べない子の指導, 周産期医学, $22: 432-436,1992$.

7 ) 二木 武, 川井 尚, 帆足英一ほか：新版 小児の 発達栄養行動 一摂食から排泄まで/生理・心理・ 臨床一, 1-89, 医歯薬出版, 東京, 1995.

8 ) 二木 武: 離乳と離乳食 (1)離乳の開始と完了, 小 児看護, $18 ： 1141-1147,1995$.

9 ) 田村康夫：吸啜から咀嚼運動への移行, 2. 吸啜の 発達と咀嚼運動の開始, ザ・クインテッセンス, $15: 6-12,1996$.

10）今井敦子：咀嚼機能評価のための米飯咀嚼に関する 研究, 補緅誌, 42:147-156, 1998.

11）塩沢光一，神山かおる，柳沢慧二：粒状試料（米飯） 咀嚼について, 米飯の物性が咀嚼行動に与える影響, 日咀嚼誌, $5: 37-42,1996$.

12) Eishima, K. : The analysis of sucking behavior in newborn infants, Early Hum Dev, 27 : 163-173, 1991.

13）田村康夫, 堀川容子, 林 努ほか: 口腔内ビデオカ メラを通してみた乳児の吸啜時舌運動と口腔周囲筋 活動の協調, 顎機能誌, 2:19-26, 1995.

14) Tamura, Y., Horikawa, Y. and Yoshida, S.: Co-ordination of tongue movements and peri-oral muscle activities during nutritive sucking, Dev Med Child Neurol, 380 : 503-510, 1996.

15）宋 政文, 田村康夫, 高柳英司ほか：吸啜運動時に おける咀嚼筋活動 第 2 報 母乳と人工乳の比較, 小 览歯誌, 30：541-550，1992.

16）松下繁, 堀川容子, 田村康夫ほか：乳児吸啜運動時 の口腔周囲筋筋活動と時間的変化，小児歯誌， 32 ： 99-110, 1995.

17）中島謙二, 青木浩子, 加藤 敬ほか：乳房および人 工乳首吸啜時の筋電図学的比較, 小児歯誌, 35 : 926-935, 1997.

18）田村厚子, 柳沢幸江, 寺元芳子ほか：摂食機能に関 する研究 第 2 報 食品の物性における筋電図学的考 察, 小览歯誌, $23: 984-992,1985$.

19）柴崎貞二, 坂入 博, 高橋修ほか: 乳幼坚用食品の 硬さについての研究，小児蒾誌，19：497-506, 1981. 